\title{
Cytogenetic and scanning study of patients receiving intra-articular injections of gold-198 and yttrium-90
}

\author{
A. C. STEVENSON AND J. BEDFORD \\ MRC Population Genetics Unit, Headington, Oxford \\ G. W. DOLPHIN, R. J. PURROTT, AND D. C. LLOYD \\ National Radiological Protection Board, Harwell, Didcot, Berks \\ A. G. S. HILL AND H. F. H. HILL \\ Oxford Regional Rheumatic Diseases Research Centre, Stoke Mandeville Hospital, Aylesbury, Bucks \\ J. M. GUMPEL \\ Rheumatology Unit, Northwick Park Hospital, Harrow, Middx \\ D. WILLIAMS \\ Department of Medical Physics, Hammersmith Hospital, London W12 \\ J. T. SCOTT \\ The Kennedy Institute of Rheumatology, London W6, and Charing Cross Hospital, London WC2 \\ N. W. RAMSEY \\ Department of Medical Physics, Charing Cross Hospital, London, WC2 \\ F. E. BRUCKNER \\ Department of Physical Medicine, St. George's Hospital, London, SWI \\ C. B. D'A. FEAR N \\ Nuffield Orthopaedic Centre, Headington, Oxford
}

An account of the chromosome damage found in the lymphocytes of thirteen patients who had received injections of gold-198 into knee joints was reported in a preliminary communication (Stevenson, Bedford, Hill, and Hill, 1971a). There were great differences in the amount of damage which followed injections of the same amount of activity in these patients. However, the mean level of damage appeared too high to be explained by the assumption either that it occurred as a result of irradiation of lymphocytes in the injected joint, or that the radionuclide was distributed throughout the whole body, for the average radiation dose to the body would only be about 0.5 rad from the gamma radiation per $\mathrm{mCi}$ of gold-198. It was suggested that the high level of chromosome damage in lymphocytes relative to the amount of activity injected was most probably due to the movement of gold from the knee along the lymphatics to the inguinal lymph nodes, where enormous numbers of lymphocytes in transit through the nodes would come within the range of the beta emission of the radionuclide.

Many patients have been treated with benefit by gold-198 or yttrium-90 intra-articular injections (Ansell, Crook, Mallard, and Bywaters, 1963; Delbarre, Cayla, Menkes, Roucayrol, Ingrand, and Aignan, 1969; Bridgman, Bruckner, and Bleehen, 1971), and it seemed important to try to assess more accurately the amount of chromosome damage in lymphocytes in order to attempt to elucidate the prognostic significance, if any, to patients from these procedures. For this reason, and because there is very little available information on the cytogenetic effects of parenterally-administered radioactive isotopes in man, it was decided to investigate further cases.

Including those reported in the preliminary paper, 48 patients who have had gold-198 injections, and 22 who have had yttrium-90 injections have now been investigated. None of these patients received any external radiotherapy. As the appendices show, blood samples from some patients were not taken until several months or years after the injections. Some were taken both before and at intervals after treatment, and some patients were scanned after injection in order to determine the distribution of the isotopes.

The colloidal gold-198 (half life $65 \mathrm{hrs)}$ and yttrium-90 (half life $64 \mathrm{hrs}$ ) were obtained from the Radiochemical Centre, Amersham, catalogue numbers GCS1P and YAS3P respectively.

The gold preparation is a colloidal suspension of metallic gold stabilized with gelatin and with particle sizes of up to $20 \mu \mathrm{m}$. Most of the activity is in the $10-13 \mu \mathrm{m}$ particles. The yttrium preparation is ionic yttrium bound to a colloidal ion exchange resin with a particle size range from 20 to $50 \mu \mathrm{m}$. 


\section{Culture techniques and materials}

Blood samples were received into sterile tubes containing lithium heparin. Most were collected by the MRC staff, but some were received by post at the MRC Population Genetics Unit, Oxford. An aliquot of the sample was then sent to the National Radiological Protection Board's Cytogenetics Laboratory at Harwell. As far as possible, cultures were started on the same day in each laboratory. It has been demonstrated that there are no significant differences in the amount of damage found in cells from blood kept at room or domestic refrigerator temperatures in the heparin tubes when the cultures have been started at intervals of up to 5 days after sampling.

In the MRC laboratory $0.5 \mathrm{ml}$. blood is added to $5 \mathrm{ml}$. culture medium consisting of $1 \mathrm{ml}$. AB group human serum (inactivated by heat), $4 \mathrm{ml}$. Eagle's Medium, MEM which contains streptomycin and penicillin (Wellcome Reagents Ltd.), $0.05 \mathrm{ml}$. heparin (Boots 4,000 $\mu \mathrm{g}$. $/ \mathrm{ml}$.), and $0.05 \mathrm{ml}$. phytohaemagglutinin (PHA) solution (Wellcome Reagents Ltd.). The mixture is sealed in a 30-ml. universal container in an atmosphere of 5 per cent. $\mathrm{CO}_{2}$ in air. After $45 \mathrm{hrs}$ in a water bath at $37^{\circ} \mathrm{C} ., 2 \mu \mathrm{g}$. $/ \mathrm{ml}$. Colcemid (Ciba Laboratories) is added, and the culture is harvested at $48 \mathrm{hrs}$.

In the NRPB laboratory $0 \cdot 15 \mathrm{ml}$. PHA is added to a mixture of $1 \mathrm{ml}$. whole blood and $1 \mathrm{ml}$. TC Bovine (calf) serum (Difco Laboratories). After centrifuging, $1 \mathrm{ml}$. of the supernatant fluid containing the leucocytes is transferred to a culture bottle containing $4 \mathrm{ml}$. Eagle's Medium, MEM. After $45 \mathrm{hrs}$ incubation at $37^{\circ} \mathrm{C}$., Colcemid is added, and the culture is harvested at $48 \mathrm{hrs}$.

RATIONALE OF THE ASSUMPTION THAT THE OBSERVED CHROMOSOME DAMAGE OCCURRED in vivo It is known that circulating lymphocytes exchange rapidly into and out of body tissues (Sharpe, Dolphin, Dawson, and Field, 1968). Some have a life span of several years in the body and seldom divide (Buckton, Smith, and Court Brown, 1967; Norman, Sasaki, Ottoman, and Fingerhut, 1965; Dolphin, Lloyd, and Purrott, in press). In culture, as described above, they are stimulated to divide by the PHA which is added to the medium. In vivo the nondividing lymphocytes are in the so-called $\mathrm{G}_{0}$ or resting stage of interphase. The chromosomes are long, single, and thread-like. When stimulated by PHA the cells pass into $G_{1}$ and on into the cell cycle. After about $24 \mathrm{hrs}$ in culture, DNA synthesis begins (the ' $S$ ' phase), as demonstrated by the uptake of $3 \mathrm{H}$-thymidine (Sasaki and Norman, 1966). When synthesis is complete, the chromosomes are fully duplicated and consist of two chromatids held together at the centromere. The post-DNA stage synthesis is known as $G_{2}$ and this lasts until the chromosomes enter mitosis.

Cells are suitable for accurate chromosome analysis only in the metaphase stage of mitosis, and the first metaphases are usually seen after $38 \mathrm{hrs}$ in culture. However, some may take as long as $65 \mathrm{hrs}$ to reach metaphase.The time from onset of culture to first metaphase depends mainly on the time taken for transformation of small lymphocytes to the blast form which is the essential preliminary to DNA synthesis. When Colcemid is added at $45 \mathrm{hrs}$, all cells then in metaphase, or reaching metaphase thereafter, are arrested. Any cells which have already passed through metaphase and have divided into daughter cells do not have sufficient time to undergo a second mitotic division in culture. It follows then that all cells analysed in metaphase from a 48-hr culture were in $\mathrm{G}_{0}$ stage in the patients, and that any chromosome breaks induced at that stage which did not restitute would be duplicated when chromatids are formed during ' $S$ ' stage. The observed breaks therefore affect the chromatid arms equally and all the aberrations are duplicated. Control cultures show that this type of damage very rarely occurs during the $G_{0}$ or $G_{1}$ phase in the early period of culture. In contrast, any damage affecting single chromatids in the chromosomes must have occurred during or after duplication, i.e. in the $S$ or $\mathbf{G}_{2}$ stages. As these stages of the cell cycle take place in the culture, any 'chromatid type' damage must have occurred there and not in vivo.

The genesis of the different types of abnormal chromosomes resulting from damage induced in $\mathrm{G}_{0}$, as seen in the next metaphase, are fully discussed in UNSCEAR (1969) and by Evans (1970). An abbreviated account of the formation of these aberrations has also been given in a previous communication (Stevenson, Bedford, Hill, and Hill, 1971b).

CRITERIA FOR SCORING CHROMOSOME ABERRATIONS In both laboratories the criteria for scoring aberrations in cells were as follows:

(1) Only cells with 46 centromeres were scored;

(2) Cells with dicentric chromosomes and/or centric rings were scored as damaged only when the appropriate acentric fragment or fragments were identifiedotherwise they were noted as incomplete cells;

(3) Cells with broken chromsomes were not scored unless the appropriate acentric fragments were identified;

(4) Acentric rings, 'minutes', and larger acentric chromosome portions were all scored as 'fragments';

(5) A standard practice of scoring one tricentric as two dicentric chromosomes was followed;

(6) Although translocations and presumptive pericentric inversions were noted, the cells with such anomalies were not scored as 'damaged' for present purposes because of the uncertainties in identification. In orceinstained chromosomes, pericentric inversions can be detected only by an apparent change in the position of the centromere relative to the ends, and this must be large for it to be noticeable. Paracentric inversions are not detectable in orcein-stained material. In translocations there has to be a considerable difference in the size of the fragments exchanged between two chromosomes before the anomaly is recognizable.

A more important reason for not scoring presumptive pericentric inversions and translocations is that it is impossible to know how they arose. As these anomalies are stable they can pass through many divisions; they may have arisen from chromatid or chromosome damage, and it is impossible to determine how many divisions have intervened between the observation of the anomaly and its induction. In contrast, when complete cells are analysed for unstable chromosome-type aberrations, the presence of at least one acentric fragment indicates that the cells are unlikely to have passed through more than one division since the damage was induced.

The newer techniques of quinacrine fluorescence and of DNA denaturing and staining with one of the Romanowsky stains (Pearson, 1972) are not as yet suitable for routinely scoring these aberrations, although by using 
such techniques, considerable damage, not recognizable with orcein staining, can readily be demonstrated.

Isochromatid gaps, chromatid gaps, chromatid breaks, and complex chromatid interchange figures were noted, but were not scored. The frequency of such post $\mathbf{G}_{0}$ damage did not appear, in either laboratory, to be higher than in the cells of control patients.

\section{Chromosome aberration data}

The complete chromosome aberration data for all patients are set out in the four appendices, and an estimate of the amount of integral activity in $\mathrm{mCi}$ days found in the regional lymph nodes in the lower abdomen (the inguinal, iliac, and para-aortic nodes) is shown for the patients who were scanned after injection. The distribution of dicentrics among the scored cells is also shown. Appendices 1 and 3 deal respectively with patients who had gold and yttrium injections and from whom blood samples were obtained several months or years later. Appendices 2 and 4 set out the information from patients who had gold or yttrium respectively and from whom blood samples were obtained before injection and at intervals thereafter. By comparison dicentric chromosomes are rarely found in control samples from the general population ( $1: 3,000$ cells), and the total of chromosomally-damaged cells is less than 1 per cent.

With the following exceptions all the injections were into knee joints. Those of G4, G24, G38, Y7, and Y9 were into finger joints and those of G12 into shoulder joints.

It is convenient in the first instance to ignore the scanning data and to consider the relationships of amounts of activity injected, intervals between injection and blood sampling, and frequencies of damaged cells and of dicentrics.

As there are big differences in the intervals after injection at which the chromosomes of the patients were analysed (1 to $99 \mathrm{mths}$ ), it is desirable to try to make some correction before aberration yields per $\mathrm{mCi}$ injected are compared.
By observing the fall in aberration yield over a period of several years in a group of patients given therapeutic external irradiation, the mean halflife of lymphocytes carrying dicentric aberrations has been estimated by Norman, Sasaki, Ottoman, and Fingerhut (1966) as 530 days with large confidence limits, and by Buckton and others (1967) as 1,600 days with 95 per cent. confidence limits of 900 to 6,700 days. In any individual patient there must be much uncertainty about the rate of fall-off of aberration yields, as this depends on the rate of turnover of lymphocytes which presumptively is influenced by experience of infection and other factors. We have taken a figure of 3 years as the half-life of lymphocytes carrying dicentrics, and on this assumption it is possible to correct the aberration yield to that expected immediately after treatment.

In terms of energy deposition there is a marked difference between the two radionuclides. The decay of $1 \mathrm{mCi}$ of gold-198 is equivalent to emitted energy of $63 \times 10^{3}$ g.rads from beta radiation plus $84 \times 10^{3}$ g.rads from gamma radiation, although only 40 per cent. of the gamma energy is deposited in the average patient, the rest escaping from the body. Hence the total energy deposition in the body from gold-198 is $63 \times 10^{3}+0.4 \times 84 \times 10^{3}=97 \times 10^{3}$ \& rads. For yttrium- 90 which emits only beta radiation. the equivalent value is about twice this, $183 \times 10$ g.rads, and all this energy is absorbed within a few $\mathrm{mm}$. of the radionuclide.

The percentage of damaged cells, as given in Appendices 1 and 3, has been plotted againt the dose in $\mathrm{mCi}$ of gold-198 and yttrium-90 in Fig. 1, which shows that there is no correlation between the amount of either radionuclide and the percentage of damaged cells, and that the damage per $\mathrm{mCi}$ is not higher in patients treated with gold-198 than in those given yttrium-90. In Fig. 2, the dicentric yield has been corrected to allow for the disappearance of lymphocytes carrying this type of aberration, using the 3year half-life as described above. Again, there is no

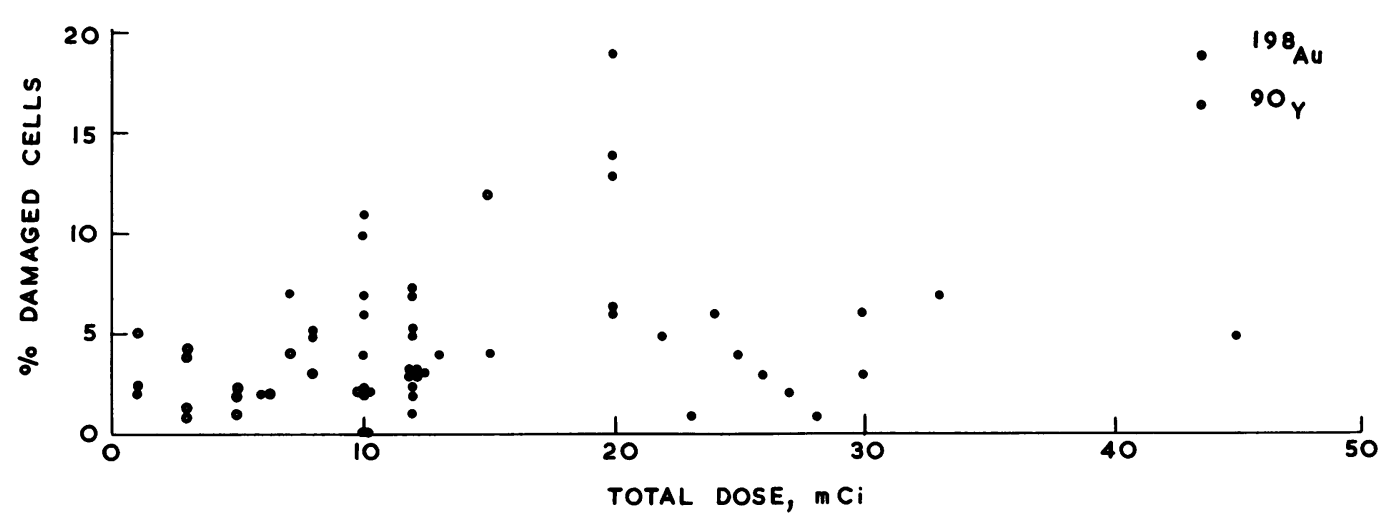

FIG. 1 Percentage of damaged cells plotted against dose of Au-198 and yttrium-90 (see Appendices 1 and 3) 
obvious correlation between the corrected dicentric yield and the quantity or type of radionuclide injected. This could be accounted for by the considerable variation between individuals, as demonstrated by the scanning results, in the proportion of injected nuclide which leaves the joint.

Appendices 2 and 4 show the findings in patients tested before and at intervals after gold-198 (2 patients) and yttrium-90 (7 patients) injections respectively. The data suggest that there are no very consistent patterns in the various patients. However, Table $I$ indicates that some damage is detectable in many patients after $24 \mathrm{hrs}$, and that, as would be expected, there is on average an increase in detectable damage up to 28 days after injection.

Table I Summary of patients tested before and after injections

\begin{tabular}{|c|c|c|c|c|c|c|}
\hline \multirow{3}{*}{$\begin{array}{l}\text { No. of } \\
\text { patients }\end{array}$} & \multirow{3}{*}{$\begin{array}{l}\text { Amount of } \\
\text { radionuclide }\end{array}$} & \multicolumn{5}{|c|}{ Dicentrics per 100 cells analysed } \\
\hline & & \multirow[t]{2}{*}{ Before } & \multicolumn{4}{|c|}{ After (days) } \\
\hline & & & 1 & 7 & 14 & 28 \\
\hline 2 & $\begin{array}{l}10 \mathrm{mCi} \\
\text { gold-198 }\end{array}$ & 0.33 & $1 \cdot 12$ & $1 \cdot 33$ & $2 \cdot 00$ & $1 \cdot 50$ \\
\hline 6 & $\underset{\text { yttrium-90 }}{5 \mathrm{mCi}}$ & 0.07 & 0.27 & 1.20 & - & 1.77 \\
\hline 1 & $\begin{array}{l}10 \mathrm{mCi} \\
\text { yttrium-90 }\end{array}$ & 0.00 & $1 \cdot 13$ & $6 \cdot 33$ & - & $4 \cdot 67$ \\
\hline
\end{tabular}

\section{Scanning data}

After gold-198 injection to the knees, patients G41 to G49 and G52 were scanned at the Charing Cross Hospital and the movement of the radionuclide to the regional lymph nodes was measured. Two methods were used for these measurements; an external surface counter collimated to accept radiation from an
$11 \mathrm{~cm}$. diameter circle at a depth $5 \mathrm{~cm}$. below the skin, and later a Mecaserto rectilinear scanner became available. In both methods calibrations were made using colloidal gold-198 and a correction for absorption in tissues was made by assuming that the nodes were at a constant depth of $5 \mathrm{~cm}$. About six measurements were made on each patient during the week after treatment, and two or three were usually made on the first day. Measurements in seven patients showed that the peak value in the lymph nodes was reached at $20 \mathrm{hrs}$. In two patients the peak was reached at $10 \mathrm{hrs}$ and in one at $40 \mathrm{hrs}$. After arrival at the nodes, very little activity escaped. Values for the time-integrated activity in $\mathrm{mCi}$-days are given in the last column in Appendix 1 for the ten patients followed.

The corrected dicentric yield found in lymphocytes of these ten patients is plotted against the integral activity in Fig. 3, which shows clearly that the dicentric yield increases with the amount of gold-198 which has escaped from the knee into the nodes. For the two patients with the highest integral activity in the nodes the dicentric yield is 14 per 100 cells. In the NRPB laboratory the relationship between the dose from cobalt- 60 gamma radiation and dicentric yield has been established for in vitro irradiation of blood (Purrott and others, 1972) and 14 dicentrics per 100 cells corresponds to a uniform dose of 160 rads. Clearly the amount of gold-198 in the body is not sufficient to account for a whole body dose of this magnitude and it must be due to selective irradiation of the lymphocytes, presumably in the regional nodes.

Ten patients treated with yttrium- 90 were scanned at the Northwick Park Hospital using a 3-in. dual detector scanner with focusing collimators. The pulse height analyser attached to these detectors was set to record a portion of the continuous spectrum of

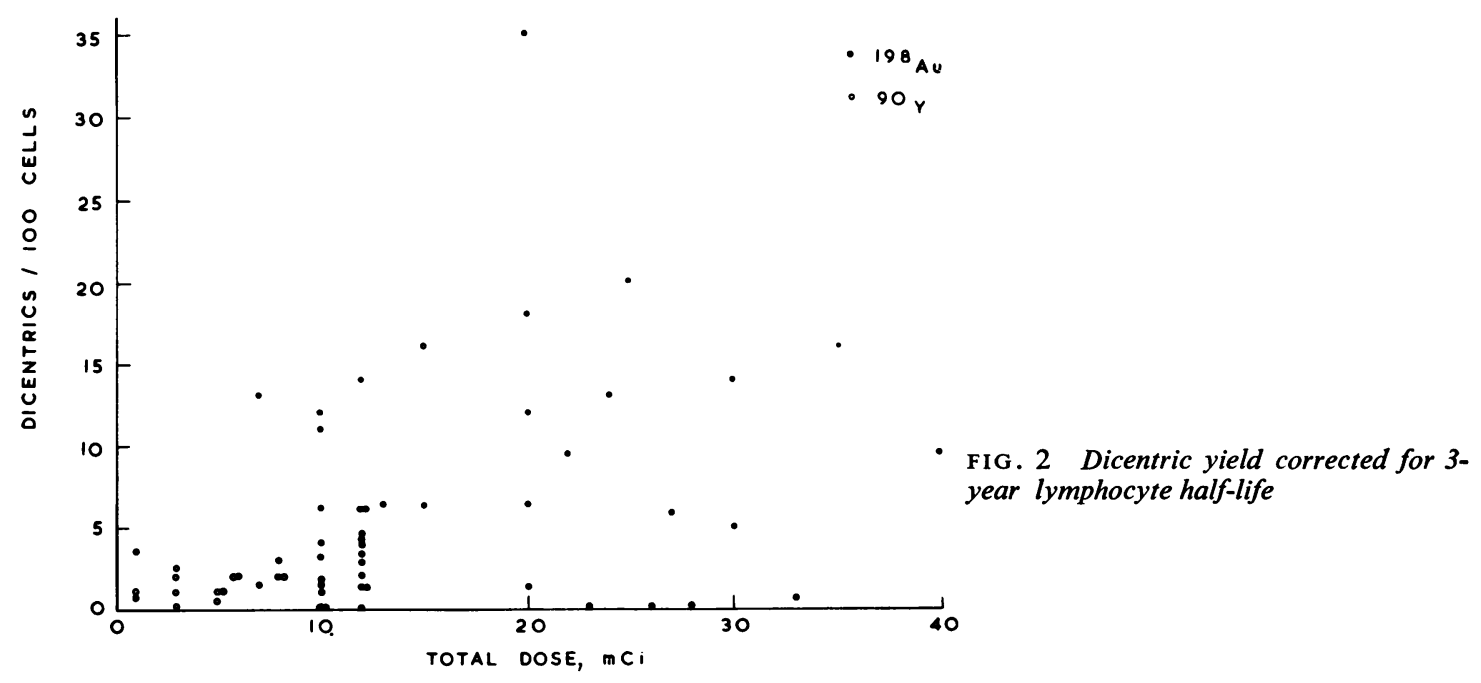




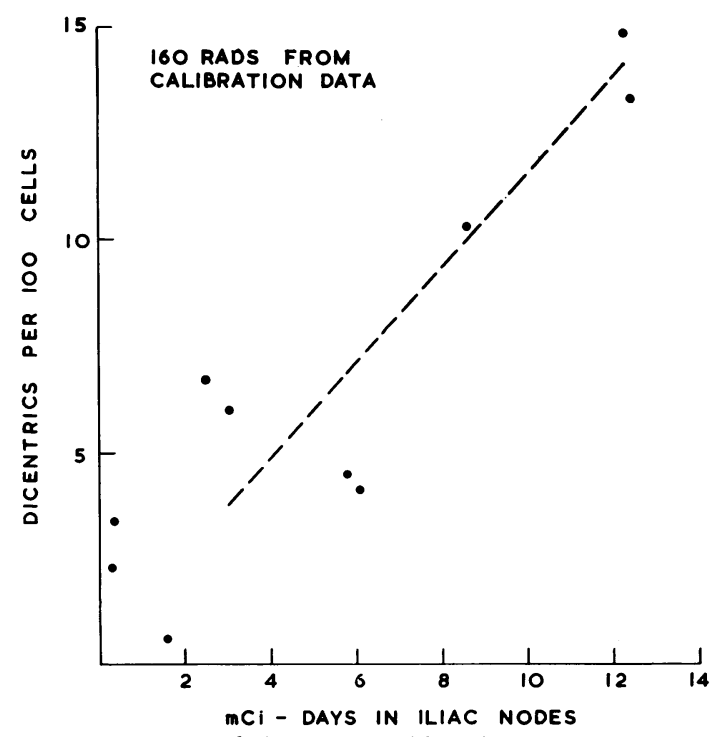

FIG. 3 Corrected dicentric yield in lymphocytes of ten patients treated with Au-198 plotted against integral activity

bremsstrahlung in the range $60-200 \mathrm{keV}$. An aluminium plate $1 \mathrm{~mm}$. thick was placed in front of each collimator to absorb beta radiation. The summed response from the two detectors was then approximately independent of the depth of the yttrium-90 when scanned in a water phantom. The uptake in the lymph nodes was found by using a quantitative scanning technique (Williams, Glass, Arnot and De Garreta, 1969), comparing the number of dots on the scan of this part of the patient with the number on a scan of a water phantom containing an aliquot of the radioactivity injected.

Of the ten patients who were scanned, only five showed significant uptake in the regional lymph nodes. Between one and three measurements were made over the lymph nodes from 2 to 7 days after injection. The time-integrated activity in the lymph nodes was estimated from these scanning measurements. The liver was also scanned in some cases but little uptake was seen which indicates that only a small amount of the colloidal yttrium escapes into the circulation where it may be taken up by the liver.

The dicentric yield found in these yttrium patients increased with the estimated integral activity $\stackrel{\text { S }}{+}$ found in the regional lymph nodes, but as the number of patients in which there was significant movement to the nodes was small (Appendices 3 and 4) a graph has not been constructed.

\section{Selective irradiation of lymphocytes}

As shown in Fig. 3, there is a good correlation between the dicentric yield and the time-integrated activity of $\vec{\omega}$ gold-198 in the regional lymph nodes, and this is o. most probably explained by selective irradiation of $\frac{0}{2}$ the lymphocytes as they pass through these nodes. To illustrate this selective irradiation, it is proposed to estimate the radiation dose and the mass of lymphocytes irradiated by reference to patients G46 and $\vec{N}$ G47. Patient G46 received $12 \mathrm{mCi}$ into each knee 은 approximately 3 years before the blood sample was taken but scanning measurements showed that no $>$ significant leakage occurred from the right knee. Hence this patient is comparable to patient G47 who received $12 \mathrm{mCi}$ to the left knee also 3 years pre- $\overrightarrow{0}$ viously. The dicentric yield and the distribution of $\omega$ cells with $0,1,2,3$, and 4 dicentrics is given in Table 1 Although the integrated amounts of gold-198 differex by a factor of 2 between these two patients, the escape to the regional lymph nodes was comparable, as shown in the last column of the Table. Consequently the data from the two patients may be combined in order to improve the statistical accuracy of the following analysis. The time-lapse between treatment and blood sampling for both patients is 3 years and as the half-life of the lymphocytes containing dicentrics is assumed to be 3 years, then the corrected yield given in the fourth row is obtained by doubling the number of dicentrics in the 700 cells for the combined data. These corrected data may be compared with the expected distribution of dicentrics among 700 cells if they follow Poisson statistics, as given in the fifth row of the Table. All previous work in the NRPB laboratory on the measurement of dicentric distributions among lymphocytes given

Table II Combined dicentric yield from patients G46 and G47 corrected for time lapse between treatment and blood sample and compared with a Poisson distribution which is expected following uniform irradiation of lymphocytes

\begin{tabular}{|c|c|c|c|c|c|c|c|c|}
\hline \multirow[t]{2}{*}{ Patient no. } & \multirow[t]{2}{*}{ Cells scored } & \multirow[t]{2}{*}{ Dic./cell } & \multicolumn{5}{|c|}{ Dicentric distribution in cells } & \multirow{2}{*}{$\begin{array}{l}\text { Estimated time integral } \\
\text { of activity } \\
\text { (mCi days) }\end{array}$} \\
\hline & & & 0 & 1 & 2 & 3 & 4 & \\
\hline $\begin{array}{l}\text { G46 } \\
\text { G47 }\end{array}$ & $\begin{array}{l}400 \\
300\end{array}$ & $\begin{array}{l}0.06 \\
0.07\end{array}$ & $\begin{array}{l}385 \\
284\end{array}$ & $\begin{array}{l}10 \\
12\end{array}$ & $\begin{array}{l}3 \\
3\end{array}$ & $\begin{array}{l}0 \\
1\end{array}$ & $\begin{array}{l}2 \\
0\end{array}$ & $\begin{array}{l}12 \cdot 45 \\
12 \cdot 2\end{array}$ \\
\hline $\begin{array}{l}\text { Total } \\
\text { Corrected }\end{array}$ & $\begin{array}{l}700 \\
700\end{array}$ & $\begin{array}{l}0 \cdot 064 \\
0 \cdot 13\end{array}$ & $\begin{array}{l}669 \\
638\end{array}$ & $\begin{array}{l}22 \\
44\end{array}$ & $\begin{array}{r}6 \\
12\end{array}$ & $\begin{array}{l}1 \\
2\end{array}$ & $\begin{array}{l}2 \\
4\end{array}$ & 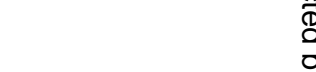 \\
\hline Poisson distribution & 700 & $0 \cdot 13$ & 615 & 80 & 5 & 0 & 0 & \\
\hline
\end{tabular}


uniform radiation doses shows that a Poisson distribution should be expected. A Poisson distribution is not obtained, however, if the lymphocytes are nonuniformly irradiated. This is most probably the case in these patients, in whom only a fraction of the lymphocytes may pass through the regional nodes to be irradiated by the beta particles from the gold198. Other cells not passing through these nodes would receive only a low average dose from the gamma radiation emitted by the radiogold in the knee or lymph nodes.

The simplest model which can be postulated for interpreting the observed dicentric distribution is one in which two fractions of lymphocytes are assumed; one irradiated uniformly and the other unirradiated. In Table III the Poisson distribution of dicentrics among 138 cells given a uniform irradiation of 380 rads is shown in the second row, and if these data are combined with 562 unirradiated cells then the total in the bottom row is in close agreement with the corrected observed data given in the fourth line of Table II. The only point of disagreement is the four cells, each with four dicentrics, which cannot be accounted for by the simple model. These could be explained by modifying the model to include a third fraction of a few per cent. of the total mass, irradiated to a dose of the order of 1,000 rads. These data are, however, not sufficient to allow the meaningful calculation of the size and radiation dose to this third fraction and they will be ignored.

A physiological interpretation of this simple model is that 20 per cent. (138 cells) of the lymphocytes in the body passed through the lymph nodes containing the gold-198, and they received a high average dose, 380 rads, during transit from the beta radiation. The other fraction, 80 per cent. (562 cells), did not pass through these nodes and received only a small average dose from the gamma radiation.

The time-integrated activity in the regional nodes of these two patients, about $12 \mathrm{mCi}$-days, corresponds to the complete decay of about $3 \mathrm{mCi}$ of gold. Most of the gamma radiation energy escapes from the nodes leaving only the beta radiation energy which is $190 \times 10^{3}$ g.rads. This energy will be almost entirely absorbed within the nodes which consist of connective tissue and structural cells as well as lymphocytes in passage. If it is assumed that only 10 per cent. of the beta radiation energy is absorbed by the lymphocytes and this leads to an average dose of 380 rads, then the mass irradiated is given by the energy absorbed in g. rads, $0 \cdot 1 \times 190 \times 10^{3}$ divided by the average dose in rads, 380 , which gives $50 \mathrm{~g}$. of lymphocytes. If this represents the irradiated fraction, 20 per cent. of the total mass of lymphocytes according to the model then the total mass is $250 \mathrm{~g}$. of lymphocytes. A value for the total mass of about the same order was previously obtained by Sharpe and others, (1968) and later by Field, Sharpe, Dawson, Andersen, Killmann, and Weeke (1972) from a study of patients extracorporeally irradiated.

There is evidence from animal experiments that only thymus-derived lymphocytes respond to PHA, but evidence from humans is not conclusive (Stockman, Gallagher, Heim, South, and Trentin, 1971). Because of this effect, $250 \mathrm{~g}$. may be a lower limit for the estimated total of lymphocytes in the body. There is no suitable case in the yttrium- 90 series on which the analysis of the observed dicentric distribution can be carried out. The number of cells in case Y24 is extensive enough but three separate injections were made at intervals. The pattern of distribution of dicentrics among the cells induced by these three injections of yttrium-90 is too complex for analysis along the lines of the two gold-198 cases above.

\section{Comparison of scores in the two laboratories}

When all results from both laboratories were available for comparison, it was found that in eleven cases the cultures had failed completely in one laboratory, or were not adequate to yield a sufficient number of scorable metaphases. It was decided in these cases that:

(i) A fresh specimen would be obtained, and analysed in both laboratories;

(ii) That the results of the first analysis in one laboratory would be ignored.

Cases in which this procedure was followed can be identified by asterisks in Appendices 1 and 2 .

In three cases in which both laboratories had satisfactory cultures, it was found that the proportions of damaged cells in the two laboratories was disturbingly different. It was decided to try to obtain further specimens and that, irrespective of the findings the published scores would be the combined findings from both specimens in the two laboratories. In one case (G25) it proved impossible to get a further

Table III Simple model of total mass of lymphocytes in the body divided into an unirradiated and irradiated fraction which combine to give observed dicentric distribution

\begin{tabular}{|c|c|c|c|c|c|c|c|c|}
\hline \multirow{2}{*}{$\begin{array}{l}\text { Total mass of lymphocytes } \\
\text { (per cent.) }\end{array}$} & \multirow[t]{2}{*}{ Cells scored } & \multirow[t]{2}{*}{ Dic./cell } & \multicolumn{5}{|c|}{ Dicentric distribution in cells } & \multirow[t]{2}{*}{ Dose (rads) } \\
\hline & & & 0 & 1 & 2 & 3 & 4 & \\
\hline $\begin{array}{lr}\text { Non-irradiated } & 80 \\
\text { Irradiated } & 20\end{array}$ & $\begin{array}{l}562 \\
138\end{array}$ & $\begin{array}{l}0 \\
0.54\end{array}$ & $\begin{array}{r}562 \\
80\end{array}$ & $\overline{44}$ & $\overline{12}$ & $\overline{2}$ & $\overline{0}$ & $\begin{array}{r}0 \\
380\end{array}$ \\
\hline Total & 700 & 0.11 & 642 & 44 & 12 & 2 & 0 & \\
\hline
\end{tabular}


specimen. In the other two (G2 and G30) the scores shown in Appendix 1 are the sum of the scores from the four specimens obtained.

In all previously published work, where amounts of chromosomal damage have been reported in normal individuals or in those exposed to mutagenic agents, the analyses of cells from culture have been undertaken in only one laboratory. It has therefore never been possible, as in the present study, to compare findings after different culture techniques had been used and the observations made by different cytologists.

The data given in Appendices 1 to 4 are the sums of the findings in the two laboratories when, with the exceptions noted, 100 cells were analysed in the MRC and 200 cells in the NRPB laboratories. In all, the frequencies of dicentric chromosomes in the MRC and NRPB laboratories (excluding all except 28-day specimens of patients followed up-Appendices 2 and 4) were respectively 310 in 8,631 cells and 417 in 13,338 cells $\left(\chi^{2}=3.41 ; \mathrm{df}=1 ; \mathrm{P}<0 \cdot 1\right)$. There is reasonable agreement in the two laboratories as to frequencies of dicentrics per 100 cells analysed from individual patients. However, there are seven pairs of observations in which the differences between findings are significant at less than 5 per cent. levels of probability.

All the findings are set out in Table IV in respect of dicentric chromosomes in the seven patients: it will be noted that for patients G46 and G48 the first culture was unsuccessful in the NRPB laboratory. Therefore, as previously noted, any findings in the MRC laboratory for that culture were not included in Appendix 1. However, they are included in Table IV. In Y 25 the difference in the findings between the two laboratories is due mainly to one cell which had eight dicentric chromosomes.
Although some of the differences between laboratories may represent observer errors, it is difficult to accept that large differences arise in this way; indeed, re-examination of the slides excludes this possibility. It may be that different types and batches of media, or small temperature fluctuations, or consistent variations during incubation, in some way influence the proportions of damaged cells reaching metaphase at $48 \mathrm{hrs}$. Work to explore these various possibilities is being planned but will take many months.

Meanwhile, however, two points should be noted:

(a) We can exclude the possibility of mutations arising in $G_{1}$ in culture, since both laboratories have large series of controls, many of which have been processed in batches with specimens from exposed individuals;

(b) It is perhaps worth stressing again that this is the first time that authors have drawn attention to the problem of large variations in findings between and within laboratories.

It is all the more essential, therefore, to regard single findings in respect of chromosome damage as estimates, the confidence limits of which are wider than those expected after random sampling of populations of cells.

\section{Discussion}

Virkunnen, Krusius, and Heiskanan (1967) have shown that, after the injection of a stable suspension of gold-198 into joints, an appreciable amount of activity leaked to the regional lymph nodes in about 90 per cent. of patients and that in some of them as much as 20 per cent. reached the nodes. Their estimates of dose to the regional nodes after the injection of about $10 \mathrm{mCi}$ of gold into knee joints

Table IV Data from seven patients in whom there were large inter-laboratory differences in findings

\begin{tabular}{|c|c|c|c|c|c|c|c|c|c|c|c|c|c|c|}
\hline \multirow{3}{*}{$\begin{array}{l}\text { Patient } \\
\text { No. }\end{array}$} & \multirow{3}{*}{$\begin{array}{l}\text { Specimen } \\
\text { no. }\end{array}$} & \multicolumn{7}{|l|}{$M R C$} & \multicolumn{6}{|l|}{$N R P B$} \\
\hline & & \multirow[t]{2}{*}{$\begin{array}{l}\text { No. of cells } \\
\text { analysed }\end{array}$} & \multicolumn{5}{|c|}{$\begin{array}{l}\text { Dicentric distribution } \\
\text { in cells }\end{array}$} & \multirow[t]{2}{*}{$\begin{array}{l}\text { Total } \\
\text { dicentrics }\end{array}$} & \multirow[t]{2}{*}{$\begin{array}{l}\text { No. of cells } \\
\text { analysed }\end{array}$} & \multicolumn{4}{|c|}{$\begin{array}{l}\text { Dicentric distribution } \\
\text { in cells }\end{array}$} & \multirow[t]{2}{*}{$\begin{array}{l}\text { Total } \\
\text { dicentrics }\end{array}$} \\
\hline & & & 0 & 1 & 2 & 3 & 4 & & & 0 & 1 & 2 & 34 & \\
\hline G2 & $\begin{array}{l}1 \\
2\end{array}$ & $\begin{array}{l}100 \\
200\end{array}$ & $\begin{array}{r}96 \\
191\end{array}$ & $\begin{array}{l}4 \\
7\end{array}$ & 1 & 1 & & $\begin{array}{r}4 \\
12\end{array}$ & $\begin{array}{l}200 \\
200\end{array}$ & $\begin{array}{l}183 \\
200\end{array}$ & 15 & 2 & & $\begin{array}{r}19 \\
0\end{array}$ \\
\hline G8 & 1 & 100 & 96 & 3 & 0 & 1 & & 6 & 200 & 200 & & & & 0 \\
\hline G18 & 1 & 100 & 88 & 8 & 4 & & & 16 & 200 & 188 & 10 & 2 & & 14 \\
\hline G42 & 1 & 100 & 92 & 5 & 1 & 2 & & 13 & 200 & 196 & 3 & 1 & & 5 \\
\hline G46 & $\begin{array}{l}1 \\
2\end{array}$ & $\begin{array}{l}100 \\
200\end{array}$ & $\begin{array}{r}95 \\
187\end{array}$ & $\begin{array}{l}3 \\
9\end{array}$ & 2 & - & 2 & $\begin{array}{r}7 \\
21\end{array}$ & 200 & $\begin{array}{l}\text { Cult } \\
198\end{array}$ & ture $\mathrm{f}$ & $\begin{array}{l}\text { failed } \\
1\end{array}$ & & 3 \\
\hline G48 & $\begin{array}{l}1 \\
2\end{array}$ & $\begin{array}{l}100 \\
200\end{array}$ & $\begin{array}{r}97 \\
196\end{array}$ & $\begin{array}{l}3 \\
1\end{array}$ & 3 & & & $\begin{array}{l}3 \\
7\end{array}$ & $\begin{array}{r}42 \\
200\end{array}$ & $\begin{array}{r}38 \\
199\end{array}$ & $\begin{array}{l}3 \\
1\end{array}$ & 0 & 1 & $\begin{array}{l}6 \\
1\end{array}$ \\
\hline Y25 & 1 & 100 & 100 & & & & & 0 & 200 & 193 & 6* & & & 14 \\
\hline
\end{tabular}

* Plus 1 cell with 8 dicentrics. 
ranged from zero to over 10,000 rads; the mean was probably about 1,000 rads.

This variation in the amount of activity leaving injected joints provided an explanation of the lack of significant correlation between the amount injected and the amount of chromosome damage found in the lymphocytes observed in the patients reported in this study. However, the frequencies of chromosomal damage, as already noted, pointed to selective irradiation of lymphocytes, as the dose to the whole body or to blood cells was so small.

It is known that, when a patient has received a uniform whole body dose of radiation, the numbers of dicentric chromosomes per cell follow a Poisson distribution which is in accord with all lymphocytes having an equal chance of exposure. However, when the same external dose is given to limited areas of the body, the distribution of dicentric chromosomes in cells no longer follows a Poisson distribution, there being undue proportions of cells with no dicentrics or with two or more dicentrics (Dolphin, 1969). The proportions depend on the fraction of the total number of lymphocytes irradiated and the average level of the radiation dose. The marked departure from Poisson distributions in data from individual patients and in the summated data indicates a highly selective irradiation of a proportion of the body's lymphocyte population.

In view of the evidence of the amount and distribution of chromosomal damage in lymphocytes in our patients, and of considerable amounts of radioactivity in regional lymph nodes previously and here reported, the most obvious explanation of our findings is that damage to lymphocytes occurs predominantly as they pass through these nodes. As is well known, there is a continuous traffic of lymphocytes between the circulating blood and the reticuloendothelial system (Ford and Gowans, 1969). The findings strongly suggest that over a relatively few days a remarkably high proportion of the lymphocytes, in the samples taken from peripheral blood, had passed through the lymph nodes draining the injected joints.

The clinical follow-up of patients receiving intraarticular injections of radioactivity shows that they benefit from the treatment and in some cases show a marked improvement which is not always achieved by other non-surgical forms of treatment. There is little or no evidence of detriment to patients and in particular no cases of leukaemia have so far been reported. However, it is known that sarcomata have occurred at the sites of injection of gold-198 in webs between the toes of two patients after its use for tracer purposes.

A patient of one of the authors (AGSH), who had an injection of $20 \mathrm{mCi}$ of gold-198 into the right knee in June, 1960, developed a reticulum cell sarcoma on the right side of the neck in 1968. He died a year later (aged 42) and there was no autopsy.

A patient of another of the authors (JTS-G41) developed hoarseness attributable to a mediastinal mass 3 years after her injection. At subsequent autopsy this was shown to be an anaplastic bronchial carcinoma.

The possibility of development of leukaemia in patients with so much evidence of lymphocyte damage must be considered. However, the evidence presented strongly suggests that the only cells or tissues which receive large doses will be the lymphocytes, the structural cells and connective tissues of the regional nodes, and, to a lesser degree, the liver. It has to be remembered that the damage of the type recorded in lymphocytes would be eliminated much more quickly in rapidly dividing tissues. On the other hand, it is likely that at least as much stable typechromosomal damage would be induced in chromosomes of these cells, and that the damage which is detectable by using ordinary orcein staining methods is perhaps only 20 per cent. of the total. 'Stable' and 'unstable' damage in cells are relative terms, and much 'stable' damage undoubtedly can cause trouble at mitosis, and give rise to further karyotypic abnormalities. However, there is no evidence that any visible chromosome aberration is causally related to any human cancer.

A summary of dose estimates for hypothetical models is given in Table $\mathrm{V}$ (overleaf) for injections of $10 \mathrm{mCi}$ of gold-198 and $5 \mathrm{mCi}$ of yttrium-90 which were typical amounts administered to patients.

The estimated treatment dose at a depth of $1 \mathrm{~mm}$. in the synovial membrane (col. 2) was calculated using a method suggested by Grahame, Ramsey, and Scott (1970), in which they assumed that half the injected activity was uniformly deposited on $50 \mathrm{~cm}^{2}$ of synovial membrane, the rest of the activity being deposited elsewhere. In col. 3 a hypothetical average dose to the knee is given and this is calculated on the assumption that 100 per cent. of the injected material is retained, and that the energy of disintegration is absorbed in $300 \mathrm{~g}$. of tissue. Lower values of this dose would be appropriate if leakage occurred.

If material leaks from the knee along the lymphatics into the regional nodes, then high radiation dose levels occur in these nodes because of the concentration of the activity into a small mass of tissue. In col. 4 the doses have been calculated assuming that 10 per cent. of the injected amount has moved into these nodes and that the mass of tissue is $10 \mathrm{~g}$. In those patients in whom the movement of activity was measured, sometimes more than 10 per cent. was found to transfer and in many cases considerably less, so that the calculated dose to these nodes is only a representative value.

Scanning data showed a small concentration in the liver and for the injected material to reach this organ it must be in a physical and chemical form which 
Table V Summary of mean radiation doses calculated using hypothetical models for the knee, regional lymph nodes, liver, whole body and lymphocytes, from gold-198 or yttrium-90, based on assumption that 10 per cent of injected activity to knee leaks to regional lymph nodes and 1 per cent. to liver

\begin{tabular}{|c|c|c|c|c|c|c|c|c|c|c|}
\hline \multirow{2}{*}{$\begin{array}{l}\text { Amount } \\
\text { injected } \\
\text { and type } \\
\text { of radiation }\end{array}$} & \multirow{2}{*}{$\begin{array}{l}\text { Estimated } \\
\text { treatment dose } \\
\text { to synovium* } \\
\text { (rads) }\end{array}$} & \multicolumn{2}{|c|}{$\begin{array}{l}100 \text { per cent. in } \\
\text { knee }(300 \mathrm{~g} .)\end{array}$} & \multicolumn{2}{|c|}{$\begin{array}{l}10 \text { per cent. in } \\
\text { regional lymph } \\
\text { nodes }(10 \mathrm{~g} .)\end{array}$} & \multicolumn{2}{|c|}{$\begin{array}{l}1 \text { per cent. in } \\
\text { liver }(1,700 \mathrm{~g} .)\end{array}$} & \multicolumn{2}{|c|}{$\begin{array}{l}100 \text { per cent. in } \\
\text { whole body } \\
(70,000 \mathrm{~g} .)\end{array}$} & \multirow{2}{*}{$\begin{array}{l}\begin{array}{l}\text { Selective } \\
\text { irradiation of } \\
\text { lymphocytes }\end{array} \\
\begin{array}{l}\text { Dose } \\
(\text { rads })\end{array}\end{array}$} \\
\hline & & $A F \dagger$ & $\begin{array}{l}\text { Dose } \\
\text { (rads) }\end{array}$ & $A F \dot{\dagger}$ & $\begin{array}{l}\text { Dose } \\
\text { (rads) }\end{array}$ & $A F \dagger$ & $\begin{array}{l}\text { Dose } \\
\text { (rads) }\end{array}$ & $A F \dagger$ & $\begin{array}{l}\text { Dose } \\
\text { (rads) }\end{array}$ & \\
\hline $\begin{array}{l}10 \mathrm{mCi} \\
\text { Gold-198 }\end{array}$ & & $\begin{array}{l}1 \\
0 \cdot 10\end{array}$ & $\begin{array}{r}2,100 \\
280\end{array}$ & $\begin{array}{l}1 \\
0.01\end{array}$ & $\begin{array}{r}6,300 \\
80\end{array}$ & $\begin{array}{l}1 \\
0 \cdot 16\end{array}$ & $\begin{array}{l}3 \cdot 7 \\
0 \cdot 8\end{array}$ & $\begin{array}{l}1 \\
0 \cdot 34\end{array}$ & $\begin{array}{l}9 \\
4\end{array}$ & 100 \\
\hline Total & 6,300 & & 2,380 & & 6,380 & & $4 \cdot 5$ & & 13 & \\
\hline $\begin{array}{l}5 \mathrm{mCi} \\
\text { Yttrium-90 }\end{array}$ & 7,200 & 1 & 3,100 & 1 & 9,100 & 1 & $5 \cdot 4$ & 1 & 13 & - \\
\hline
\end{tabular}

- After Grahame and others (1970), who assumed that half the injected activity was deposited uniformly on $50 \mathrm{~cm}^{2}$ synovial membrane, and calculated the dose at $1 \mathrm{~mm}$. depth for gold-198 and $2 \mathrm{~mm}$. depth for yttrium-90 in the membrane.

$\dagger$ AF-absorbed fraction-the energy released by radioactive decay which is retained in the organ. Value is obtained from Snyder, Ford, Warner, and Fisher (1969).

$\ddagger$ Dose to lymphocytes estimated from an assumed initial dicentric yield of $5 / 100$ cells, a representative value from Fig. 3 , which is equivalent to 100 rads obtained from the in vitro calibration curve (Dolphin and others, in press). A representative value for yttrium-90 is not available, 1 but may be the same as that for gold-198.

allows it to pass through the lymphatic system into the circulation from which it is removed by phagocytic action of the Kuppfer cells in the liver. The radionuclide reaching the liver may be in one of several forms; small colloidal particles in suspension, attached to protein, complexed by biological chelates, or in soluble form. It is unlikely that a large fraction of the injected radionuclide will follow this pathway and in Table $\mathrm{V}$ a representative calculation of the dose to the liver is made, assuming that only 1 per cent. of the injected activity reaches it.

The dose to the whole body (col. 6) has been calculated by assuming that the radionuclide is distributed throughout the body mass, and this is an average dose which may be useful in assessing risks of cancer induction after radiation.

In the last column of Table V, the mean dose to the lymphocytes has been estimated from the observed chromosome aberration frequency. The value of five dicentrics per 100 cells is a representative value for the ten patients given gold injections and who were also scanned. This aberration frequency corresponds to about 100 rads by reference to calibration curves (Purrott and others, 1972).

It is known from the follow-up studies of survivors of the atomic bombs in the two Japanese cities (Beebe, Kato, and Land, 1970) and from radiotherapy patients, as reviewed by Dolphin and Marley (1969), that malignant neoplasms may be induced by radiation in most tissues. The tissues of the patients given intra-articular injections which received the highest doses are the knee and synovial membrane, the regional lymph nodes, and the lymphocytes, but there is no parallel experience in any other irradiated group of patients who have been studied. Hence a comparison with other irradiated groups has little validity in the prognosis of cancer risk. Under these circumstances the simplest approach is to assume that the average dose to the whole body per injection, as given in col. 6, carries a risk of 100 cancers per million persons per rad to the whole body (Dolphin and Marley, 1969). Hence a tentative risk estimate, in round values, is about 1 in 1,000 of patien? treated with $10 \mathrm{mCi}$ of gold- 198 or $5 \mathrm{mCi}$ of yttrium 90. This risk is small compared with the risk of naturally occurring cancer, which is 31 in 1,000 for $\overrightarrow{\mathrm{a}}$ 50-year-old person in England and Wales dying of cancer in the next 10 years. However, it is comparable with the risk of a person in the middle of his third decade of life dying of cancer during the next 10 years. It may therefore be argued that the treatment should normally be reserved for older patients unless no alternative is available.

To lower the small risk of late development of malignancy, it is necessary to investigate the cause of the leakage of activity from the joint with a view to its prevention. Whole body irradiation could be reduced by use of the beta emitting yttrium-90 rather than gold-198.

\section{Summary}

Seventy rheumatoid arthritis patients treated with $\mathcal{N}$ intra-articular gold-198 or yttrium-90 injections have $N$ been independently examined in two laboratories for chromosome damage in peripheral blood lymphocytes. There was good agreement between the laboratories. In nine cases blood samples were analysed before and at intervals after treatment. Twenty $\cong$ patients were scanned for the distribution of the $T$ radionuclide and varying levels of leakage from the joint to the regional lymph nodes was detected. Here the nuclide selectively irradiates lymphocytes in transit through the nodes. Aberration data from two 
patients were used to estimate the total body mass of lymphocytes at about $250 \mathrm{~g}$. The significance of the damage to lymphocytes is considered in terms of the risk to patients from this therapy.

We are most grateful to Dr. G. Wiernik, Dr. A. H. Laing and Dr. C. Paine, and to Dr. F. Ellis who treated some of the first patients in the Churchill Hospital, Oxford, for letting us investigate these patients.

We are also indebted to Dr. F. W. Wright for helpful discussions, to many colleagues in general practice who collected specimens for us or permitted us to visit their patients, and to Miss Elaine Eltham for much technical assistance in the NRPB laboratory.

\section{References}

Ansell, B. M., Crook, A., Mallard, J. R., ANd Bywaters, E. G. L. (1963) Ann. rheum. Dis., 22, 435 (Evaluation of intra-articular colloidal gold $\mathrm{au}^{198}$ in the treatment of persistent knee effusions)

BeEbe, G. W., Kato, H., AND LAND, C. E. (1970) 'JNIH-ABCC Life span study, Hiroshima-Nagasaki, Report 5, Mortality and radiation dose, October 1950-September 1966' ABCC Technical Report 11-1970. Atomic Bomb Casualty Commission, Japan

Bridgman, J. F., Bruckner, F. E., ANd Bleehen, N. M. (1971) Ann. rheum. Dis., 30, 180 (Radioactive yttrium $\left({ }^{90}\right.$ Y) in the treatment of rheumatoid knee effusions)

Buckton, K. E., Smith, P. G., AND Court Brown, W. M. (1967) 'The estimation of lymphocyte lifespan from studies on males treated with $X$-rays for ankylosing spondylitis', in 'Human Radiation Cytogenetics: Proc. int. Symp., Edinburgh, 1966', ed. H. J. Evans, W. M. Court Brown, and A. S. McLean, p. 106. North Holland Publishing Co., Amsterdam

Delbarre, F., Cayla, J., Menkes, C., Roucayrol, J-C., Ingrand, J., and Aignan, M. (1969) Rev. Prat., 19, 2737 (Le traitement des rhumatismes par les synoviortheses)

DolPHIN, G. W. (1969) 'Biological dosimetry with particular reference to chromosome aberration analysis', in 'Handling of Radiation Accidents, IAEA-SM-119/4'. International Atomic Energy Agency, Vienna

— AND MARLEY, W. G. (1969) 'AHSB(RP)R93 Risk evaluation in relation to the protection of the public in the event of accidents at nuclear installations'. United Kingdom Atomic Energy Authority, Harwell

Evans, H. J. (1970) 'Population cytogenetics and environmental factors', in 'Human Population Cytogenetics', ed. P. A. Jacobs, W. H. Price, and P. Law, p. 192. University Press, Edinburgh

Field, E. O., Sharpe, H. B. A., Dawson, K. B., Andersen, V., Killmann, S. A., And Weeke, E. (1972) Blood, 39, 39 (Turnover rate of normal blood lymphocytes and exchangeable pool size in man, calculated from analysis of chromosomal aberrations sustained during extracorporeal irradiation of the blood)

Ford, W. L., AND Gowans, J. L. (1969) Seminars in Hematology, 6, 67 (The traffic of lymphocytes)

Grahame, R., Ramsey, N. W., AND Scott, J. T. (1970) Ann. rheum. Dis., 29, 159 (Radioactive colloidal gold in chronic knee effusions with Baker's cyst formation)

Norman, A., Sasaki, M. S., Ottoman, R. E., and Fingerhut, A. G. (1965) Science, 147, 745 (Lymphocyte lifetime in women)

$-,-1,-1$ (1966) Blood, 27, 706 (Elimination of chromosome aberrations from human lymphocytes)

PeARSON, P. (1972) J. med. Genet., 9, 264 (Use of new staining techniques for human chromosome identification: Review article)

Purrott, R. J., Dolphin, G. W., Lloyd, D. C., Rickard, B., AND Eltham, E. (1972) "National Radiation Protection Board-R5 (Harwell, Didcot, Berks) (The study of chromosome aberration yield in human lymphocytes as an indicator of radiation dose. II. A review of cases investigated in 1970-71).

SASAKI, M. S., AND Norman, A. (1966) Nature (Lond.), 210, 913 (Proliferation of human lymphocytes in culture)

Sharpe, H. B. A., Dolphin, G. W., Dawson, K. B., AND Field, E. O. (1968) Cell Tissue Kinet., 1, 263 (Methods for computing lymphocyte kinetics in man by analysis of chromosomal aberrations sustained during extracorporeal irradiation of the blood)

SNYDER, W. S., Ford, M. R., WARNeR, G. G., AND Fisher, H. L. (1969) J. nucl. Med., 10, Suppl. 3 (Estimates of absorbed fractions for monoenergetic photon sources uniformly distributed in various organs of a heterogeneous phantom)

Stevenson, A. C., Bedford, J., Hill, A. G. S., ANd Hill, H. F. H. (1971a) Lancet, 1, 837 (Chromosome damage in patients who had had intra-articular injections of radioactive gold)

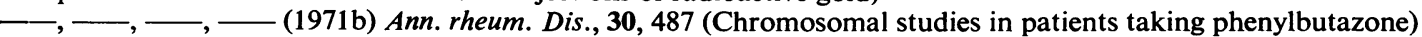

Stockman, G. D., Gallagher, M. T., Heim, L. R., South, M. A., and Trentin, J. J. (1971) Proc. Soc. exp. Biol. $(N . Y), 136,$.980 (Differential stimulation of mouse lymphoid cells by phytohemagglutinin and pokeweed mitogen)

UnSCEAR (1969) 'Report of the United Nations Scientific Committee on the Effects of Atomic Radiation'. General Assembly Official Records, Twenty Fourth Session. Supplement No. 13 (A/7613). United Nations, New York

VirkKunen, M., KRusius, F.-E., AND HeisKanen, T. (1967) Acta rheum. scand., 13, 81 (Experience of intra-articular administration of radioactive gold)

Williams, E. D., Glass, H. I., Arnot, R. N., AND De Garreta, A. G. (1969) Med. Radioisotope Scintigraphy, 1, 665 (A dual detector scanner for quantitative uptake and organ volume studies) 
Appendix 1 Patients who had gold-198 injections and were only tested at an interval thereafter

\begin{tabular}{|c|c|c|c|c|c|c|c|c|c|c|c|c|c|c|c|c|}
\hline \multirow[t]{5}{*}{ No. } & \multirow[t]{5}{*}{$\operatorname{Sex}$} & \multirow{5}{*}{$\begin{array}{l}\text { Age } \\
(y r s)\end{array}$} & \multirow{5}{*}{$\begin{array}{l}\text { No. of } \\
\text { joints } \\
\text { injected }\end{array}$} & \multirow{5}{*}{$\begin{array}{l}\text { Total } \\
\text { dose } \\
(m C i)\end{array}$} & \multirow{5}{*}{$\begin{array}{l}\text { Mean } \\
\text { interval } \\
\text { (mths) }\end{array}$} & \multicolumn{10}{|c|}{ Cytogenetic findings } & \multirow{5}{*}{$\begin{array}{l}\text { Integral } \\
\text { lymph node } \\
\text { uptake } \\
\text { (mCi days) }\end{array}$} \\
\hline & & & & & & \multicolumn{3}{|l|}{ Total cells } & \multirow{2}{*}{\multicolumn{2}{|c|}{$\begin{array}{l}\text { Dicentric } \\
\text { chromosomes }\end{array}$}} & \multirow{2}{*}{\multicolumn{2}{|c|}{$\begin{array}{l}\begin{array}{l}\text { Centric ring } \\
\text { chromosomes }\end{array} \\
\end{array}$}} & \multirow{3}{*}{\multicolumn{3}{|c|}{$\begin{array}{l}\text { Distribution of } \\
\text { dicentrics: } \\
\text { Cells with numbers of } \\
\text { dicentrics }\end{array}$}} & \\
\hline & & & & & & \multirow[t]{3}{*}{ Analysed } & \multicolumn{2}{|c|}{ Damaged } & & & & & & & & \\
\hline & & & & & & & & & \multirow{2}{*}{ No. } & Per 100 & No. & Per 100 & & & & \\
\hline & & & & & & & & cent. & & & & & 0 & 1 & 2345678 & \\
\hline G1 & $\mathbf{F}$ & 40 & 1 & 12 & 22 & 300 & 8 & $2 \cdot 7$ & 3 & $1 \cdot 0$ & 0 & 0.0 & 297 & 3 & & \\
\hline $2 *$ & $\mathbf{F}$ & 49 & 3 & 30 & 55 & 700 & 41 & $5 \cdot 8$ & 35 & $5 \cdot 0$ & 1 & $0 \cdot 1$ & 670 & 26 & 31 & \\
\hline 4 & $\mathbf{M}$ & 67 & 2 & 20 & 7 & 300 & 42 & $14 \cdot 0$ & 47 & $15 \cdot 7$ & 3 & $1 \cdot 0$ & 272 & 20 & $\begin{array}{lllllll}5 & 1 & 0 & 0 & 1 & 0 & 1\end{array}$ & \\
\hline 5 & $\mathbf{M}$ & 75 & 1 & 10 & 13 & 300 & 30 & $10 \cdot 0$ & 14 & $4 \cdot 7$ & 0 & 0.0 & 286 & 14 & & \\
\hline 6 & $\mathbf{F}$ & 68 & 1 & 8 & 1 & 300 & 15 & $5 \cdot 0$ & 10 & 3.0 & 0 & 0.0 & 290 & 10 & & \\
\hline 8 & $\mathbf{F}$ & 58 & 1 & 8 & 1 & 300 & 14 & $4 \cdot 7$ & 6 & $2 \cdot 0$ & 2 & 0.7 & 296 & 3 & 01 & \\
\hline 9 & $\mathbf{F}$ & 73 & 2 & 20 & 5 & 300 & 17 & $5 \cdot 7$ & 17 & $5 \cdot 7$ & 3 & $1 \cdot 0$ & 288 & 7 & 5 & \\
\hline 10 & $\mathbf{M}$ & 55 & 1 & 15 & 27 & 300 & 13 & $4 \cdot 3$ & 12 & $4 \cdot 0$ & 0 & 0.0 & 293 & 4 & 12 & \\
\hline 11 & $\mathbf{F}$ & 57 & 1 & 10 & 32 & 300 & 11 & 3.7 & 2 & 0.7 & 1 & $0 \cdot 3$ & 298 & 2 & & \\
\hline 12 & $\mathbf{M}$ & 70 & 2 & 26 & 81 & 300 & 8 & $2 \cdot 7$ & 1 & 0.3 & 0 & 00 & 299 & 1 & & \\
\hline 13 & $\mathbf{M}$ & 71 & 1 & 25 & 99 & 300 & 11 & $3 \cdot 7$ & 9 & $3 \cdot 0$ & 0 & 0.0 & 294 & 5 & $\begin{array}{lll}0 & 0 & 1\end{array}$ & \\
\hline 14 & $\mathbf{M}$ & 63 & 2 & 12 & 23 & 300 & 16 & $5 \cdot 3$ & 11 & $3 \cdot 7$ & 1 & 0.3 & 289 & 11 & & \\
\hline $15 t$ & $\mathbf{F}$ & 61 & 1 & 12 & 41 & 400 & 13 & $3 \cdot 2$ & 6 & $1 \cdot 5$ & 0 & 0.0 & 394 & 6 & & \\
\hline $16 \dagger$ & $\mathbf{F}$ & 64 & 1 & 10 & 39 & 400 & 8 & $2 \cdot 0$ & 1 & 0.2 & 0 & 0.0 & 399 & 1 & & \\
\hline 17 & $\mathbf{F}$ & 33 & 3 & 28 & 31 & 300 & 3 & $1 \cdot 0$ & 1 & 0.3 & 0 & 0.0 & 299 & 1 & & \\
\hline 18 & $\mathbf{M}$ & 75 & 2 & 20 & 8 & 300 & 38 & $12 \cdot 7$ & 30 & $10 \cdot 0$ & 5 & $1 \cdot 7$ & 276 & 18 & 6 & \\
\hline 19 & $\mathbf{F}$ & 71 & 2 & 20 & 12 & 300 & 57 & $19 \cdot 0$ & 83 & $27 \cdot 7$ & 3 & 1.0 & 257 & 22 & 125103 & \\
\hline 20 & $\mathbf{F}$ & 43 & 2 & 20 & 22 & 300 & 17 & $5 \cdot 7$ & 4 & $1 \cdot 3$ & 0 & 0.0 & 296 & 4 & & \\
\hline 21 & $\mathbf{M}$ & 74 & 2 & 27 & 34 & 300 & 5 & $1 \cdot 7$ & 8 & $2 \cdot 7$ & 1 & 0.3 & 296 & 2 & 101 & \\
\hline 22 & $\mathbf{M}$ & 69 & 1 & 12 & 23 & 300 & 15 & $5 \cdot 0$ & 8 & $2 \cdot 7$ & 0 & 0.0 & 292 & 8 & & \\
\hline 23 & $\mathbf{F}$ & 38 & 1 & 10 & 2 & 300 & 5 & $1 \cdot 7$ & 3 & $1 \cdot 0$ & 0 & $0 \cdot 0$ & 297 & 3 & & \\
\hline 25 & $\mathbf{F}$ & 18 & 1 & 12 & 36 & 150 & 1 & 0.7 & 0 & 0.0 & 0 & 0.0 & 150 & 0 & & \\
\hline 26 & $\mathbf{F}$ & 28 & 1 & 10 & 20 & 300 & 6 & $2 \cdot 0$ & 5 & $1 \cdot 7$ & 0 & 0.0 & 297 & 2 & 01 & \\
\hline 27 & $\mathrm{~F}$ & 16 & 2 & 10 & 66 & 300 & 1 & 0.3 & 1 & 0.3 & 0 & 0.0 & 299 & $\overline{1}$ & & \\
\hline 29 & $\mathbf{F}$ & 29 & 2 & 22 & 23 & 700 & 34 & $4 \cdot 9$ & 45 & 6.4 & 1 & 0.1 & 674 & 17 & $\begin{array}{lllll}5 & 0 & 3 & 0 & 1\end{array}$ & \\
\hline $30 \dagger$ & $\mathbf{M}$ & 70 & 2 & 13 & 15 & 300 & 13 & $4 \cdot 3$ & 16 & $5 \cdot 3$ & 0 & 0.0 & 291 & 6 & 2000001 & \\
\hline 31 & $\mathbf{F}$ & 44 & 1 & 10 & 5 & 300 & 33 & $11 \cdot 0$ & 33 & $11 \cdot 0$ & 7 & $2 \cdot 3$ & 277 & 18 & $\begin{array}{llll}3 & 0 & 1 & 1\end{array}$ & 4 \\
\hline 32 & $\mathbf{F}$ & 55 & 2 & 23 & 40 & 241 & 2 & 0.8 & 0 & 0.0 & 0 & 0.0 & 241 & 0 & & 응 \\
\hline $33 \dagger$ & $\mathbf{F}$ & 31 & 4 & 45 & 24 & 400 & 21 & $5 \cdot 2$ & 23 & $5 \cdot 7$ & 0 & 0.0 & 381 & 17 & 101 & \\
\hline 34 & $\mathbf{M}$ & 49 & 3 & 6 & 36 & 300 & 6 & $2 \cdot 0$ & 2 & 0.7 & 0 & 0.0 & 298 & 2 & & बె \\
\hline $35 \dagger$ & $\mathbf{F}$ & 20 & 1 & 10 & 28 & 400 & 1 & 0.2 & 0 & 0.0 & 0 & 0.0 & 400 & & & \\
\hline 36 & $\mathbf{M}$ & 44 & 1 & 10 & 10 & 300 & 20 & $6 \cdot 7$ & 26 & $8 \cdot 7$ & 2 & 0.7 & 284 & 11 & 131 & \\
\hline 37 & $F$ & 40 & 1 & 10 & 15 & 300 & 19 & $6 \cdot 3$ & 10 & $3 \cdot 3$ & 0 & 0.0 & 292 & 6 & 2 & \\
\hline 38 & $\mathrm{~F}$ & 67 & 1 & 1 & 17 & 300 & 6 & $2 \cdot 0$ & 1 & $0 \cdot 3$ & 0 & $0 \cdot 0$ & 299 & 1 & & \\
\hline $39 \dagger$ & $\mathbf{F}$ & 16 & 3 & 30 & 47 & 400 & 11 & $2 \cdot 7$ & 7 & $1 \cdot 7$ & 0 & 0.0 & 396 & 2 & 11 & \\
\hline 40 & $\mathbf{F}$ & 22 & 1 & 33 & 8 & 300 & 5 & $6 \cdot 7$ & 1 & 0.3 & 0 & 0.0 & 299 & 1 & & \\
\hline 41 & $\mathbf{F}$ & $45 ?$ & 1 & 12 & 331 & 300 & 5 & $1 \cdot 7$ & 1 & 0.3 & 0 & 0.0 & 299 & 1 & & 1.56 \\
\hline 42 & $\mathrm{~F}$ & 54 & 1 & 7 & 38 & 300 & 21 & $7 \cdot 0$ & 18 & $6 \cdot 0$ & 1 & 0.3 & 288 & 8 & 22 & $8 \cdot 65$ \\
\hline 43 & $\mathbf{F}$ & 65 & 1 & 12 & 40 & 300 & 8 & $2 \cdot 7$ & 3 & 1.0 & 1 & 0.3 & 297 & 3 & & 0.23 \\
\hline 44 & $\mathbf{F}$ & 77 & 1 & 12 & 34 & 300 & 21 & $7 \cdot 0$ & 9 & $3 \cdot 0$ & 2 & 0.7 & 294 & 4 & 11 & $3 \cdot 0$ \\
\hline 45 & $\mathbf{M}$ & 58 & 1 & 12 & 31 & 300 & 9 & $3 \cdot 0$ & 7 & $2 \cdot 3$ & 0 & 0.0 & 297 & 0 & 21 & $6 \cdot 1$ \\
\hline $46 \dagger$ & $\mathbf{F}$ & 59 & 2 & 24 & 39 & 400 & 24 & $6 \cdot 0$ & 24 & 6.0 & 2 & 0.5 & 385 & 10 & 302 & $12 \cdot 45$ \\
\hline 47 & $\mathbf{F}$ & 66 & 1 & 12 & 36 & 300 & 21 & $7 \cdot 0$ & 21 & $7 \cdot 0$ & 0 & 0.0 & 284 & 12 & 31 & $12 \cdot 2$ \\
\hline $48 \dagger$ & $\mathbf{M}$ & 69 & 1 & 12 & 38 & 400 & 9 & $2 \cdot 2$ & 8 & $2 \cdot 0$ & 0 & 0.0 & 395 & 2 & 3 & $5 \cdot 8$ \\
\hline 49 & F & 68 & 1 & 12 & 36 & 300 & 9 & 3.0 & 5 & $1 \cdot 7$ & 0 & 0.0 & 296 & 3 & 1 & 0.31 \\
\hline 52 & $\mathbf{F}$ & 61 & 1 & 12 & 31 & 400 & 36 & $9 \cdot 0$ & 15 & 3.7 & 8 & 0.0 & 387 & 11 & 2 & 2.4 \\
\hline
\end{tabular}

Appendix 2 Patients who were tested before gold-198 injections and at intervals thereafter

\begin{tabular}{|c|c|c|c|c|c|c|c|c|c|c|c|c|c|c|c|}
\hline \multirow[t]{4}{*}{ No. } & \multirow[t]{4}{*}{ Sex } & \multirow{4}{*}{$\begin{array}{l}\text { Age } \\
\text { (yrs) }\end{array}$} & \multirow{4}{*}{$\begin{array}{l}\text { No. of } \\
\text { joints } \\
\text { injected }\end{array}$} & \multirow{4}{*}{$\begin{array}{l}\text { Total } \\
\text { dose } \\
(m C i)\end{array}$} & \multirow{4}{*}{$\begin{array}{l}\text { Mean } \\
\text { interval } \\
\text { (days) }\end{array}$} & \multicolumn{9}{|c|}{ Cytogenetic findings } & \multirow{4}{*}{$\begin{array}{l}\text { Integral } \\
\text { lymph node } \\
\text { uptake } \\
\text { (mCi days) }\end{array}$} \\
\hline & & & & & & \multicolumn{3}{|l|}{ Total cells } & \multicolumn{2}{|c|}{$\begin{array}{l}\text { Dicentric } \\
\text { chromosomes }\end{array}$} & \multicolumn{2}{|c|}{$\begin{array}{l}\text { Centric ring } \\
\text { chromosomes }\end{array}$} & \multirow{2}{*}{\multicolumn{2}{|c|}{$\begin{array}{l}\text { Distribution of } \\
\text { dicentrics: } \\
\text { Cells with numbers of } \\
\text { dicentrics }\end{array}$}} & \\
\hline & & & & & & \multirow[t]{2}{*}{ Analysed } & \multicolumn{2}{|c|}{ Damaged } & & & & & & & \\
\hline & & & & & & & No. & $\begin{array}{l}\text { Per } \\
\text { cent. }\end{array}$ & & cells & & cells & 0 & 12345678 & \\
\hline G50 & $\mathbf{M}$ & 50 & 1 & 10 & $\begin{array}{c}\text { Before } \\
1 \\
7 \\
14 \\
28\end{array}$ & $\begin{array}{l}300 \\
300 \\
300 \\
300 \\
300\end{array}$ & $\begin{array}{r}1 \\
8 \\
16 \\
8 \\
13\end{array}$ & $\begin{array}{l}0 \cdot 3 \\
2 \cdot 7 \\
5 \cdot 3 \\
2 \cdot 7 \\
4 \cdot 3\end{array}$ & $\begin{array}{l}0 \\
5 \\
8 \\
5 \\
8\end{array}$ & $\begin{array}{l}0 \cdot 0 \\
1 \cdot 7 \\
2 \cdot 3 \\
1 \cdot 7 \\
2 \cdot 7\end{array}$ & $\begin{array}{l}0 \\
0 \\
0 \\
0 \\
1\end{array}$ & $\begin{array}{l}0.0 \\
0.0 \\
0.0 \\
0.0 \\
0.3\end{array}$ & $\begin{array}{l}300 \\
296 \\
292 \\
295 \\
292\end{array}$ & $\begin{array}{ll}4 & 1 \\
8 & \\
5 & \\
8 & \end{array}$ & \\
\hline G51 & $\mathbf{M}$ & 44 & 2 & 10 & $\begin{array}{c}\text { Before } \\
1 \\
7 \\
14 \\
28\end{array}$ & $\begin{array}{l}300 \\
100 \\
300 \\
300 \\
300\end{array}$ & $\begin{array}{r}4 \\
0 \\
1 \\
11 \\
3\end{array}$ & $\begin{array}{l}1 \cdot 3 \\
0 \cdot 0 \\
0 \cdot 3 \\
3 \cdot 7 \\
1 \cdot 0\end{array}$ & $\begin{array}{l}2 \\
0 \\
0 \\
7 \\
1\end{array}$ & $\begin{array}{l}0.7 \\
0.0 \\
0.0 \\
2.3 \\
0.3\end{array}$ & $\begin{array}{l}0 \\
0 \\
0 \\
0 \\
1\end{array}$ & $\begin{array}{l}0.0 \\
0.0 \\
0.0 \\
0.0 \\
0.3\end{array}$ & $\begin{array}{l}298 \\
100 \\
300 \\
293 \\
299\end{array}$ & $\begin{array}{l}7 \\
1\end{array}$ & \\
\hline
\end{tabular}

3 
Appendix 3 Patients who had yttrium-90 injections and were tested at an interval thereafter

\begin{tabular}{|c|c|c|c|c|c|c|c|c|c|c|c|c|c|c|c|}
\hline \multirow[t]{5}{*}{ No. } & \multirow[t]{5}{*}{ Sex } & \multirow{5}{*}{$\begin{array}{l}\text { Age } \\
(y r s)\end{array}$} & \multirow{5}{*}{$\begin{array}{l}\text { No. of } \\
\text { joints } \\
\text { injected }\end{array}$} & \multirow{5}{*}{$\begin{array}{l}\text { Total } \\
\text { dose } \\
(m C i)\end{array}$} & \multirow{5}{*}{$\begin{array}{l}\text { Mean } \\
\text { interval } \\
\text { (mths) }\end{array}$} & \multicolumn{9}{|c|}{ Cytogenetic findings } & \multirow{5}{*}{$\begin{array}{l}\text { Integral } \\
\text { lymph node } \\
\text { uptake } \\
\text { (mCi days) }\end{array}$} \\
\hline & & & & & & \multicolumn{3}{|c|}{ Total cells } & \multicolumn{2}{|c|}{$\begin{array}{l}\text { Dicentric } \\
\text { chromosomes }\end{array}$} & \multicolumn{2}{|c|}{$\begin{array}{l}\text { Centric ring } \\
\text { chromosomes }\end{array}$} & \multirow{2}{*}{\multicolumn{2}{|c|}{$\begin{array}{l}\text { Distribution of } \\
\text { dicentrics: } \\
\text { Cells with numbers of } \\
\text { dicentrics }\end{array}$}} & \\
\hline & & & & & & \multirow[t]{3}{*}{ Analysed } & \multicolumn{2}{|c|}{ Damaged } & \multirow{3}{*}{ No. } & \multirow{3}{*}{$\begin{array}{l}\text { Per } 100 \\
\text { cells }\end{array}$} & & \multirow{3}{*}{$\begin{array}{l}\text { Per } 100 \\
\text { cells }\end{array}$} & & & \\
\hline & & & & & & & No. & & & & & & & & \\
\hline & & & & & & & & cent. & & & & & $\begin{array}{ll}0 & 1\end{array}$ & 12345678 & \\
\hline Y1 & $\mathbf{F}$ & 48 & 1 & 12 & 22 & 300 & 5 & $1 \cdot 7$ & 1 & 0.3 & 0 & 0.0 & 299 & 1 & \\
\hline 2 & $\mathbf{F}$ & 65 & 1 & 8 & 22 & 300 & 10 & $3 \cdot 3$ & 4 & $1 \cdot 3$ & 0 & 0.0 & 296 & 4 & \\
\hline 3 & $\mathbf{F}$ & 62 & $i$ & 7 & 25 & 300 & 13 & $4 \cdot 3$ & 3 & 1.0 & 2 & 0.7 & 297 & 3 & \\
\hline 4 & $\mathbf{F}$ & 40 & 1 & 6 & 22 & 300 & 6 & $2 \cdot 0$ & 4 & $1 \cdot 3$ & 0 & 0.0 & 296 & 4 & \\
\hline 7 & $\mathbf{F}$ & 50 & 1 & 1 & 22 & 300 & 16 & $5 \cdot 3$ & 7 & $2 \cdot 3$ & 0 & 0.0 & 293 & 7 & \\
\hline 9 & $\mathbf{F}$ & 58 & 1 & 1 & 23 & 300 & 5 & 1.7 & 1 & $0 \cdot 3$ & 0 & 0.0 & 299 & 1 & \\
\hline 10 & $\mathbf{M}$ & 56 & 1 & 3 & 21 & 300 & 2 & 0.7 & 0 & 0.0 & 0 & 0.0 & 300 & 0 & \\
\hline 11 & $\mathbf{M}$ & 62 & 1 & 3 & 21 & 300 & 12 & 4.0 & 4 & $1 \cdot 3$ & 0 & 0.0 & 296 & 4 & \\
\hline $13^{*}$ & $\mathbf{F}$ & 60 & 1 & 3 & 25 & 400 & 5 & $1 \cdot 2$ & 2 & 0.5 & 0 & 0.0 & 398 & 2 & \\
\hline 14 & $\mathbf{F}$ & 62 & 1 & 3 & 21 & 300 & 12 & 4.0 & 5 & 1.7 & 1 & $0 \cdot 3$ & 295 & 5 & \\
\hline 8 & $\mathbf{F}$ & 61 & 1 & 5 & 4 & 300 & 5 & 1.7 & 2 & 0.7 & 0 & 0.0 & 298 & 2 & 0.22 \\
\hline $18^{*}$ & $\mathbf{F}$ & 54 & 1 & 5 & 9 & 400 & 7 & 1.7 & 3 & 0.7 & 0 & 0.0 & 397 & 3 & No uptake \\
\hline $19 *$ & $\mathbf{M}$ & 31 & i & 5 & 9 & 400 & 4 & 1.0 & 1 & 0.2 & 0 & 0.0 & 399 & 1 & $0 \cdot 27$ \\
\hline 20 & $\mathbf{M}$ & 71 & 2 & 10 & 5 & 300 & 5 & 1.7 & i & 0.3 & 0 & 0.0 & 299 & 1 & No uptake \\
\hline $24 *$ & $\mathbf{F}$ & 60 & 3 & 15 & 9 & 600 & 70 & $11 \cdot 7$ & 82 & $13 \cdot 7$ & 6 & $1 \cdot 0$ & 5523 & $\begin{array}{lllll}30 & 8 & 5 & 4 & 1\end{array}$ & $5 \cdot 2$ \\
\hline
\end{tabular}

* Because of failure of culture from first specimen in the one laboratory, only findings from a repeat specimen are included.

\section{Appendix 4 Patients who were tested before yttrium-90 injections and at intervals thereafter}

\begin{tabular}{|c|c|c|c|c|c|c|c|c|c|c|c|c|c|c|c|c|}
\hline \multirow[t]{5}{*}{ No. } & \multirow[t]{5}{*}{$\operatorname{Sex}$} & \multirow{5}{*}{$\begin{array}{l}\text { Age } \\
\text { (yrs) }\end{array}$} & \multirow{5}{*}{$\begin{array}{l}\text { No. of } \\
\text { joints } \\
\text { injected }\end{array}$} & \multirow{5}{*}{$\begin{array}{l}\text { Total } \\
\text { dose } \\
(m C i)\end{array}$} & \multirow{5}{*}{$\begin{array}{l}\text { Meqn } \\
\text { interval } \\
(\text { days })\end{array}$} & \multicolumn{10}{|c|}{ Cytogenetic findings } & \multirow{5}{*}{$\begin{array}{l}\text { Integral } \\
\text { lymph node } \\
\text { uptake } \\
\text { (mCi days) }\end{array}$} \\
\hline & & & & & & \multicolumn{3}{|l|}{ Total cells } & \multirow{2}{*}{\multicolumn{2}{|c|}{$\begin{array}{l}\text { Dicentric } \\
\text { chromosomes }\end{array}$}} & \multirow{2}{*}{\multicolumn{2}{|c|}{$\begin{array}{l}\text { Centric ring } \\
\text { chromosomes }\end{array}$}} & \multirow{3}{*}{\multicolumn{3}{|c|}{$\begin{array}{l}\text { Distribution of } \\
\text { dicentrics: } \\
\text { Cells with numbers of } \\
\text { dicentrics }\end{array}$}} & \\
\hline & & & & & & \multirow{3}{*}{ Analysed } & \multirow{2}{*}{\multicolumn{2}{|c|}{ Damaged }} & & & & & & & & \\
\hline & & & & & & & & & No. & Per 100 & No. & Per 100 & & & & \\
\hline & & & & & & & No. & $\begin{array}{l}\text { Per } \\
\text { cent. }\end{array}$ & & & & & 0 & 12 & $\begin{array}{llllll}34 & 5 & 6 & 7 & 8\end{array}$ & \\
\hline Y15 & $\mathbf{M}$ & 52 & 1 & 5 & $\begin{array}{c}\text { Before } \\
1 \\
7 \\
14 \\
28\end{array}$ & $\begin{array}{l}300 \\
300 \\
300 \\
200 \\
300\end{array}$ & $\begin{array}{r}0 \\
3 \\
16 \\
8 \\
15\end{array}$ & $\begin{array}{l}0.0 \\
1.0 \\
5.3 \\
4.0 \\
5.0\end{array}$ & $\begin{array}{l}0 \\
2 \\
6 \\
4 \\
8\end{array}$ & $\begin{array}{l}0.0 \\
0.7 \\
2 \cdot 0 \\
2.0 \\
2 \cdot 7\end{array}$ & $\begin{array}{l}0 \\
0 \\
0 \\
1 \\
1\end{array}$ & $\begin{array}{l}0.0 \\
0.0 \\
0.0 \\
0.5 \\
0.3\end{array}$ & $\begin{array}{l}300 \\
298 \\
294 \\
196 \\
292\end{array}$ & $\begin{array}{l}2 \\
6 \\
4 \\
8\end{array}$ & & $0 \cdot 34$ \\
\hline $\mathbf{Y} 16$ & $\mathbf{F}$ & 45 & 1 & 5 & $\begin{array}{c}\text { Before } \\
1 \\
7 \\
14 \\
32\end{array}$ & $\begin{array}{l}300 \\
100 \\
300 \\
200 \\
300\end{array}$ & $\begin{array}{l}4 \\
0 \\
6 \\
2 \\
3\end{array}$ & $\begin{array}{l}1.3 \\
0.0 \\
2.0 \\
1.0 \\
1.0\end{array}$ & $\begin{array}{l}1 \\
0 \\
1 \\
1 \\
1\end{array}$ & $\begin{array}{l}0.3 \\
0.0 \\
0.3 \\
0.5 \\
0.3\end{array}$ & $\begin{array}{l}0 \\
0 \\
0 \\
0 \\
0\end{array}$ & $\begin{array}{l}0.0 \\
0.0 \\
0.0 \\
0.0 \\
0.0\end{array}$ & $\begin{array}{l}299 \\
100 \\
299 \\
199 \\
299\end{array}$ & $\begin{array}{l}1 \\
1 \\
1 \\
1\end{array}$ & & No uptake \\
\hline Y17 & $\mathbf{F}$ & 54 & 1 & 5 & $\begin{array}{l}\text { Before } \\
1 \\
7 \\
14 \\
28\end{array}$ & $\begin{array}{l}300 \\
100 \\
300 \\
200 \\
300\end{array}$ & $\begin{array}{r}0 \\
0 \\
10 \\
13 \\
18\end{array}$ & $\begin{array}{l}0.0 \\
0.0 \\
3.0 \\
6.5 \\
7.3\end{array}$ & $\begin{array}{r}0 \\
0 \\
8 \\
8 \\
14\end{array}$ & $\begin{array}{l}0.0 \\
0.0 \\
2 \cdot 7 \\
4 \cdot 0 \\
3 \cdot 7\end{array}$ & $\begin{array}{l}0 \\
0 \\
0 \\
0 \\
1\end{array}$ & $\begin{array}{l}0.0 \\
0.0 \\
0.0 \\
0.0 \\
0.3\end{array}$ & $\begin{array}{l}300 \\
100 \\
292 \\
192 \\
289\end{array}$ & $\begin{array}{ll}6 & 1 \\
8 & 0 \\
8 & 3\end{array}$ & & 0.50 \\
\hline Y21 & $\mathbf{F}$ & 74 & 1 & 5 & $\begin{array}{l}\text { Before } \\
1 \\
7 \\
28\end{array}$ & $\begin{array}{l}300 \\
300 \\
300 \\
158\end{array}$ & $\begin{array}{l}0 \\
2 \\
3 \\
1\end{array}$ & $\begin{array}{l}0.0 \\
0.7 \\
1.0 \\
0.6\end{array}$ & $\begin{array}{l}0 \\
1 \\
2 \\
0\end{array}$ & $\begin{array}{l}0.0 \\
0.3 \\
0.7 \\
0.0\end{array}$ & $\begin{array}{l}0 \\
0 \\
0 \\
0\end{array}$ & $\begin{array}{l}0.0 \\
0.0 \\
0.0 \\
0.0\end{array}$ & $\begin{array}{l}300 \\
299 \\
298 \\
158\end{array}$ & $\begin{array}{l}1 \\
2\end{array}$ & & No uptake \\
\hline$Y 22$ & $\mathbf{F}$ & 61 & 1 & 5 & $\begin{array}{l}\text { Before } \\
1 \\
7 \\
14\end{array}$ & $\begin{array}{l}300 \\
300 \\
300 \\
300\end{array}$ & $\begin{array}{l}0 \\
0 \\
2 \\
5\end{array}$ & $\begin{array}{l}0 \cdot 0 \\
0 \cdot 0 \\
0 \cdot 7 \\
1 \cdot 7\end{array}$ & $\begin{array}{l}0 \\
0 \\
1 \\
1\end{array}$ & $\begin{array}{l}0 \cdot 0 \\
0 \cdot 0 \\
0 \cdot 3 \\
0 \cdot 3\end{array}$ & $\begin{array}{l}0 \\
0 \\
0 \\
0\end{array}$ & $\begin{array}{l}0.0 \\
0.0 \\
0.0 \\
0.0\end{array}$ & $\begin{array}{l}300 \\
300 \\
299 \\
299\end{array}$ & $\begin{array}{l}1 \\
1\end{array}$ & & No uptake \\
\hline $\mathbf{Y 2 3}$ & $\mathbf{F}$ & 68 & 2 & 10 & $\begin{array}{l}\text { Before } \\
1 \\
7 \\
28\end{array}$ & $\begin{array}{l}300 \\
266 \\
300 \\
300\end{array}$ & $\begin{array}{r}0 \\
6 \\
31 \\
23\end{array}$ & $\begin{array}{r}0 \cdot 0 \\
2 \cdot 3 \\
10 \cdot 3 \\
7 \cdot 7\end{array}$ & $\begin{array}{r}0 \\
3 \\
19 \\
14\end{array}$ & $\begin{array}{l}0 \cdot 0 \\
1 \cdot 1 \\
6 \cdot 3 \\
4 \cdot 7\end{array}$ & $\begin{array}{l}0 \\
0 \\
4 \\
0\end{array}$ & $\begin{array}{l}0.0 \\
0.0 \\
1.7 \\
0.0\end{array}$ & $\begin{array}{l}300 \\
263 \\
282 \\
287\end{array}$ & $\begin{array}{rr}3 & \\
17 & 1 \\
12 & 1\end{array}$ & & No scan \\
\hline Y25 & $\mathbf{F}$ & 60 & 1 & 5 & $\begin{array}{r}1 \\
7 \\
14 \\
28 \\
\end{array}$ & $\begin{array}{l}100 \\
300 \\
300 \\
300\end{array}$ & $\begin{array}{r}2 \\
9 \\
9 \\
15\end{array}$ & $\begin{array}{l}2 \cdot 0 \\
3.0 \\
3 \cdot 0 \\
5 \cdot 0\end{array}$ & $\begin{array}{r}0 \\
5 \\
4 \\
14\end{array}$ & $\begin{array}{l}0.0 \\
1.7 \\
1.3 \\
4.7 \\
\end{array}$ & $\begin{array}{l}0 \\
0 \\
1 \\
3\end{array}$ & $\begin{array}{l}0.0 \\
0.0 \\
0.3 \\
1.0\end{array}$ & $\begin{array}{l}100 \\
295 \\
296 \\
293\end{array}$ & $\begin{array}{l}5 \\
4 \\
60\end{array}$ & $\begin{array}{lllllll}0 & 0 & 0 & 0 & 0 & 1\end{array}$ & No scan \\
\hline
\end{tabular}

